\title{
Geliştirilen FTT Kursunun Sınıf Öğretmenlerinin Fen Bilimleri Öğretimine Etkisi*
}

\author{
Sinan Çınar**, Salih Çepni****
}

Makale Geliş Tarihi: 07/05/2020

Makale Kabul Tarihi: 28/09/2020

DOI: $10.35675 /$ befdergi.733502

$\ddot{O} z$

Fen-Teknoloji-Toplum [FTT] yaklaşımın amacı okullardaki fen eğitimini bilimsel sunumların ötesine taşlyarak öğrencilere toplumsal ve çevresel problemleri çözmenin bir metodu olarak fen ve teknolojinin rolünü gösteren bir yaklaşımdır. Bu çalışmada, sınıf öğretmenlerinin FTT yaklaşımına dayalı fen bilimleri öğretimi yapabilmeleri için gerekli olan bilgi ve beceriyi kazanmalarını amaçlayan bir HïE kurs programı geliştirilmiş, uygulanmış ve kursa katılımc sınıf öğretmenlerinin öğretim uygulamaları üzerine etkililiği araştırılmıştır. Araştırmanın çalışma grubunu Rize ilinde görev yapan sınıf öğretmenleri arasından gönüllük esasın dayalı olarak seçilen 15 sını öğretmeni oluşturmaktadır. Araştırma yöntemi olarak Özel Durum araştırma yöntemin kullanıldığı çalışmada, veriler; anket, gözlem ve doküman analizi incelemesi yolu ile toplanmıştır. Elde edilen bulgulara göre gelişstirilen kursun sınıf öğretmenlerinin FTT arasındaki ilişkiyi kavramalarına ve sınıflarda FTT yaklaşımına dayalı fen öğretimi yapma bilgi ve becerisi kazanmasına önemli etkisi olduğu ortaya çıkmıştır. Bu durumda FTT yaklaşımına dayalı kurs programına benzer çalışmaların diğer branş ögretmen ve ögretmen adayları için düzenlemesinin faydalı olabileceği düşünülmektedir.

Anahtar Kelimeler: Fen bilimleri öğretimi, FTT yaklaşımı, hizmet-içi eğitim, sınıf ögretmenleri

\section{The Effect of The Developed STS Course on Elemantry Teachers' Science Teaching}

\section{Abstract}

The aim of the Science-Technology-Society [STS] approach is to show students the role of science and technology as a method of solving social and environmental problems by bringing science education beyond the scientific presentations. In this study, an course program, which *Bu çalışma birinci yazarın Karadeniz Teknik Üniversitesi'nde hazırladığı "Sınıf Öğretmenleri İçin Fen-Teknoloji-Toplum (FTT) Yaklaşımına Yönelik Bir Hizmet-İçi Eğitim Kurs Programı Geliştirilmesi ve Etkinliliğinin Araştırılması"' başlıklı doktora tezinden üretilmiştir.

**Recep Tayyip Erdoğan Üniversitesi, Eğitim fakültesi, Temel Eğitim bölümü, Okul Öncesi Eğitimi Anabilim Dalı, Rize, Türkiye, sinan.cinar@erdogan.edu.tr, ORCID: 0000-0002-52088986

*** Uludağ Üniversitesi, Eğitim fakülte, Matematik ve Fen Bilimleri Eğitimi bölümü, Fen Bilgisi Eğitimi Anabilim Dalı, Bursa, Türkiye, cepnisalih@yahoo.com, ORCID: 0000-00032343-8796

Kaynak Gösterme: Çınar, A., \& Çepni, S. (2021). Geliştirilen FTT kursunun sınıf öğretmenlerinin fen bilimleri öğretimine etkisi. Bayburt Eğitim Fakültesi Dergisi, 16(31), 103 127. https://doi.org/10.35675/befdergi.733502. 
aims at gaining the knowledge and skills necessary for the elemantary teachers to teach science based on STS approach, was developed, implemented and the effectiveness of the participant teachers on the teaching practices was investigated. The study group of the research consists of 15 elemantary teachers selected among the class teachers working in Rize province on a voluntary basis. In the study, in which the Special Case research method was used as a research method, the data; It was collected through survey, observation and document analysis review. The course, which was developed according to the findings obtained, turned out to have a significant impact on the elemantary teachers' understanding of the relationship between science, technology and society and gaining the knowledge and skills of teaching science based on STS approach in classrooms. In this case, it is thought that it may be beneficial to organize course studies based on STS approach for other branch teachers and prospective teachers.

Keywords: Elemantary Teachers, In-Service Education, Science Education, STS Approach

\section{Giriş}

Günümüz bilim ve teknolojisinin insan hayatını ve toplumu daha çok etkiler hale gelmesiyle birlikte ülkeler geleceği açısından, bu gelişmeleri ekonomik kalkınmaya katkı sağlayacak şekilde kullanılabilen ve toplum üzerindeki olumsuz etkilerini anlaya bilen bireylere olan ihtiyacı giderek artmıştır. Toplumdaki bu hızlı değişimin eğitime etkisi ise, eğitimin, toplumun ihtiyaç duyduğu becerilere sahip bireyleri yetiştirmesidir. Fen, teknoloji ve toplum arasındaki etkileşimleri fark eden ve bu yönde karar verebilen-fen okuryazar1- birey olarak öğrencileri yetiştirmek de fen öğretim programların genel amaçları haline gelmiş ve fen, teknoloji ve toplum disiplinleri arasındaki etkileşimi vurgulayan Fen-Teknoloji-Toplum [FTT] yaklaşımı fen öğretim içeriğinin yeniden yapılanmasına neden olmuştur (van Eijck \& Roth, 2013). FTT yaklaşımı fen, teknoloji ve toplum arasındaki ilişkiyi vurgulayan ve bu farklı disiplinden elde edilen bilgileri işleyerek yeni bilgiler üreten ilişkisel bir yaklaşımdır (Autieri, Amirshokoohi \& Kazempour, 2016; Smitha \& Aruna, 2014). Aikenhead'e (2005) göre FTT yaklaşımının amacı, fenin uygulamalarını ve sonuçlarını sosyal boyutlarıyla anlayan fen okur-yazarı vatandaşlar yetiştirmektir (Chowdhury, 2016).

Uluslararası alanda birçok fen öğretim programını büyük çapta etkileyen Framework for K-12 Science Education (NRC, 2012) ve Next Generation Science Standards (NRC, 2013) gibi raporların tanımladığı fen okuryazarlığı tanımı incelediğinde de fen okuryazarlığının fen-teknoloji-toplum gibi ortak temalar altında toplandığı görülmektedir (Devi \& Aznam, 2019). Dolayısıyla günümüz fen bilgisi öğretimin amacı olan bireylerin fen okuryazarlığının geliştirilmesinde FTT yaklaşımın kullanılması akla yatkın bir yaklaşımdır (Yalaki, 2014). Diğer taraftan araştırmacılara göre FTT yaklaşımı felsefi olarak yapısalcı öğrenme kuramına dayanmaktadır göre yapısalcı kuramın sınıflarda uygulanmasının iyi bir örneğidir (Aikenhead 2006; Kousa, Aksela \& Savec, 2018; Yager, 2009). Bu bağlamda FTT yaklaşımının uygulandığı sınıf ortamı geleneksel yaklaşımın uygulandığı sınıf 
ortamından farklı bir yapıya sahiptir (Aikenhead, 2006). FTT dayalı fen programının uygulandığı sınıflarda ögrrenme ortamı fen-teknoloji-toplum teması etrafinda yapılandırılmakta ve fen ve teknoloji kaynaklı toplumsal sorunlar disiplinler arası bir pedagojik araç olarak kullanılmaktadır (Kousa, Aksela \& Savec, 2018; Primastuti \& Atun, 2018). Bu ortamda öğrenciler fen öğrenimine fen ve teknoloji ile ilgili merak duyduğu bir toplumsal problem veya sorunla başlamakta, sonra problemi araştırmakta, grup içerisinde tartışmakta ve çözümler üretmekte, çözümle ilgili kararlar vermekte ve paylaşmaktadır (Yager, 2009). Ayrıca bu süreçte öğrenciler toplumsal veya çevresel sorunlar hakkında karar verirken ve çözüm üretirken birçok zihinsel etkinliği de kullanmaktadır;

$\checkmark \quad$ Problemi tanımlamada ve çözmede kendi bilgilerini kullanma,

$\checkmark \quad$ Yaratıcılıklarını geliştirme,

$\checkmark \quad$ Bilgi ve delillere dayalı harekete geçme,

$\checkmark \quad$ Etkili bir şekilde fen ile iletişim kurma,

$\checkmark \quad$ Fen ve teknolojiye karşı pozitif tutum,

$\checkmark \quad$ Nasıl öğrendiğini bilme gibi davranışları da kazanır (Firmino vd., 2019, Nuutinen, Kärkkäinen v\& Keinonen, 2011; Primastuti \& Atun 2018; Pimvichai, Yuenyong \& Buaraphan, 2019; Wongsila \& Yuenyong, 2019).

Görüldüğü gibi öğretmenlerin fen öğretiminde sınıflarda FTT ilişkisini kullanması feni sınıfta bilimsel sunumların ötesine taşımakta ve öğrencilerin fen ve teknolojinin toplumsal ve çevresel problemlerin çözümünde önemli bir metot olduğunu kavramasını sağlamaktadır (Yener, Aksüt, Kiras \& Yener, 2018). Diğer taraftan fenteknoloji-toplum ilişkisinin kurulmadığı bir sınıfta fen okuryazarlığ 1 kavramı eksik kalmakla birlikte, hedeflenen öğrenmenin de gerçekleşeceğini söylemek de oldukça güçtür. Meyer ve James (2002) yaptığı bir çalışmada fen bilgisi öğretmenlerinin fen ve teknoloji konularının sosyal boyutunun öğretiminde sosyal bilgiler öğretmenlerinin işbirliğine ihtiyaç duyduklarını ve bu iş birliğinin çeşitli nedenlerden ötürü sağlanamadığını bu yüzden fen sınıflarında FTT yaklaşımını tam olarak uygulanmadığını ve daha çok bir proje veya ödev çalışması olarak kullandığını tespit etmiştir. Benzer olarak Amirshokoohi (2016) de sınıf öğretmenlerinin fen ve teknoloji alanındaki çalışmaların toplumun üzerine nasıl bir etkisi olduğu konusunda yeterli bilgilerinin olmamasından dolayı sınıflarında FTT konularına yer vermediğini ve FTT yaklaşımının öğrenci seviyesinin üstesinde bir yaklaşım olarak nitelendirdiklerini ortaya çıkarmıştır.

$\mathrm{Bu}$ bağlamda FTT yaklaşımın başarısını etkileyen en önemli faktörün öğretmenlerin fen, teknoloji ve toplum arasındaki ilişkiyi anlamlı bir şekilde kavramaları ve bu disiplinleri birbirine entegre etmede kullanacağı öğretim yöntemlerinin seçimlerinin olduğu söylenebilir (Amirshokoohi, 2016; Chowdhury 
2016; Mansour, 2010; Vazquez Alonso, Garcia Carmona, Manassero Mas v\& Bennassar Roig, 2013). Bundan dolayı FTT yaklaşımının sınıfta başarı bir şekil de uygulanması ve geliştirilmesi için öğretmenlerin hem hizmet-öncesi hem de hizmetiçi eğitim süreçlerinde onların FTT ile ilgili düşüncelerinin incelemesi ve düşüncelerindeki olası tutarsılılılarla yüzleşmesi için yeterli firsatlar içermesi gerekmektedir (Amirshokoohi, 2016; Kousa, Aksela \& Savec, 2018). Ayrica öğretmenlerin FTT yaklaşımına dayalı bir eğitim sürecini girmesi, yaklaşımla ilgili kendi teorik anlayışlarını oluşturmalarına, uygulamada uygun öğretim yöntemlerini seçmelerine ve başarılı bir şeklide uygulamalarına önemli bir katkı sağlayabilir (Mansour, 2010, Pimvichai, Yuenyong \& Buaraphan, 2019).

\section{Problem Durumu}

Öğrencilerin fen ile ilgili konularda ilk önce sınıf öğretmenleri ile etkileşime girdikleri düşünüldüğünde, ilkokulda etkili bir fen eğitiminin gerçekleştirilmesi için sınıf öğretmenlerinin feni bilimsel sunumların ötesine taşıyarak öğrencilerine toplumsal ve çevresel problemleri çözmenin bir metodu olarak fen ve teknolojinin rolünü gösterecek yaklaşımları sınıflarında kullanması oldukça önemlidir (Yener vd., 2018). Bennet, Hogart ve Lubben (2005) göre toplumu oluşturan bireylerin fen ve teknoloji okur-yazarı olması için özellikle ilköğretim okullarında fen öğretiminde FTT yaklaşımın yer alması gerektiğini ve öğretmenlerinde bu doğrultuda eğitilmesi gerektiğini vurgulamaktadır. Alan yazın incelediğinde ise bu durumun böyle olmadığı, sınıf öğretmenlerinin fen, teknoloji ve toplum arasındaki ilişki hakkında yeterli bilgilerinin olmamasından dolayı, FTT konularına çok fazla ilgi duymadığı ve sınıflarda FTT yaklaşımına dayalı bir öğretim yapmaktan kaçındığı görülmektedir (Amirshokkohi, 2010; 2016). Ayrıca araştırmalar sınıf öğretmenlerinin FTT yaklaşımının derslerde öğretim stratejisinin olarak kullanılmasının ders içeriğin derinliğinin ele alınmasına izin vermeyeceğini ve öğrencilerin başarılı olmayacağını bu nedenle FTT konularının derste işlenmesinin ilkokul seviyesine uygun olmadığını daha çok orta ve lise seviyelerine uygun olduğu şeklinde düşüncelere de sahip olduklarını vurgulanmaktadır (Amirshokoohi, 2016; Autieri, Amirshokoohi \& Kazempour, 2016). Bu durumda sınıf öğretmenlerinin inançlarının incelemesi ve inançlarındaki olası tutarsızlıklarla yüzleşmesi için firsatlar içeren eğitimler ile desteklenmesi onların sınıflarında FTT eğitimini uygulanmasına önemli bir etken olacağı düşünülmektedir. Alan yazın bu doğrultuda incelediğinde ise çalışmaların büyük bir bölümü fen bilgisi öğretmenleri ve öğretmen adaylarının FTT eğitimi ile ilgili algıları veya FTT tabanlı öğretmen eğitimi kurslarının fen bilgisi öğretmen ve öğretmen adayları görüşleri üzerindeki etkisi konusunda (örnek olarak; Halwany, Zouda, Pouliot, \& Bencze, 2017; Kousa, Aksela \& Savec, 2018; Öztürk \& Doğan, 2013; Vazquez Alonso, Garcia Carmona, Manassero Mas \& Bennassar Roig, 2013) yapıldığı görülmektedir. Sınıf öğretmen ve adaylarının FTT eğitimi ile ilgili algıları veya FTT tabanlı öğretmen eğitimi kurslarının onların inançları üzerindeki etkisi konusunda çok az araştırma yapılmıştır (Amirshokkohi, 2016). Bu bağlamda sınıf öğretmenlerinin FTT yaklaşımı konusunda mesleki gelişimlerini sağlamak amacıyla 
çalışmalarının çok az olması problem durumu olarak görülmüş̧ ve sınıf öğretmenlerine yönelik dokuz günlük bir HİE-içi kurs geliştirilmiş, uygulanmış ve etkililiği araştırılmıştır. Bu bağlamda araştırmanın alt problemleri;

Geliştirilen HİE kursu

1. sınıf öğretmenlerinin fen, teknoloji ve toplum ilişkisi hakkındaki düşüncelerinin değişiminde ne kadar etkili olmuştur?

2. sınıf öğretmenlerinin FTT yaklaşımına dayalı fen öğretimi yapmada gerekli olan bilgi ve becerileri kazandırmada ne kadar etkili olmuştur?

\section{Yöntem}

Geliştirilen HİE kurs çalışması Rize ilinde görev yapan sınıf öğretmenleri ile Recep Tayyip Erdoğan Üniversitesi Eğitim Fakültesinde yürütülmüştür. HİE kursun etkililiğinin araştırılmasında özel durum araştırma yöntemi benimsenmiştir. $\mathrm{Bu}$ araştırma yöntemi araştırmacıya geliştirilen kursun üzerinde yoğunlaşmasına, kursun 15 sınıf öğretmeni üzerinde etkililiğini sebep-sonuç ve değişkenlerin karşılıklı ilişkisi anlamasına önemli katkı sağlamıştır. Çalışmada geliştirilen kursun öğretmenlerin FTT ilişkisi anlamadaki etkisini belirlemek için FTTA anketi, öğretmenlerin HİE kazanım seviyesini belirlemek için ders planlarının Doküman analizi ve sınıf öğretmenlerinin FTT yaklaşımına dayalı fen öğretimi yapma yeterliliklerini belirlemek için BORAN gözlem ölçeği kullanılmıştır.

\section{Çalışma Grubu}

Çalışma grubu Rize ilinde görev yapmakta olan sınıf öğretmenleri arasından seçilerek oluşturulmuştur. Çalışma grubu oluşturulmadan önce ilde bulunan bütün sınıf öğretmenlerine çalışma ile ilgili bilgilendirme yapılmış ve gönüllülük esasına dayanarak isteyenlerle ile iletişime geçilmiştir. Araştırma gönüllü 31 sınıf öğretmeni ile gerçekleştirilmiştir. Tablo 2'den görüldüğü gibi HİE kursun pilot uygulama aşamasında bu öğretmenlerden 16'sı ile çalışma yapılmıştır. Pilot uygulama çalışma esnasında ortaya çıkan eksiklikler düzenlenmiş ve HİE kursun asıl uygulama çalışma için hazır hale getirilmiştir. Asıl uygulama aşamasında 15 sınıf öğretmeni (9 Erkek, 6 Kadın) ile çalışma yapılmıştır. Ayrıca asıl uygulama aşamasından sonrası sınıf öğretmenlerinin kursta edindikleri bilgi ve beceriyi sınıflarında fen bilimleri öğretimlerine yansıtma durumları derinlemesine araştırmak için 15 öğretmen arasından gönüllü olarak seçilen 6 sınıf öğretmeni ile HïE kursun izleme değerlendirme aşaması yürütülmüştür (Tablo 1).

Tablo 1.

HİE Kursun Farklı Aşamalarında Araştırmaya Katılan Çalışma Grubu

\begin{tabular}{cc}
\hline HiE Kursun Aşamaları & Çalışma grubu \\
\hline Pilot uygulama & 16 öğretmen \\
\hline
\end{tabular}




\begin{tabular}{cc}
\hline Esas uygulama & 15 Öğretmen \\
İzleme Değerlendirme & 6 Öğretmen \\
\hline
\end{tabular}

\section{HİE süreci ve hie'nin geliștirilmesi}

$\mathrm{Bu}$ çalışmada planlanan HİE programı geliştirme çalışmasında, eğitim sürecini bir sistem olarak ele alan ve hedeflere ulaşmak için sistemi oluşturan tüm unsurların birlikte ve etkili çalışmasını teşvik eden sistem yaklaşım modeli kullanılmıştır (Yalın, Hedges ve Özdemir, 1996).

Tablo 2.

\section{HİE Kurs Programının Hazırlamasında Sistem Yaklașımı Modeli}

\begin{tabular}{|c|c|}
\hline Aşamalar & İçerik \\
\hline İhtiyaç Analizi & $\begin{array}{c}\text { HIE' e ihtiyaç duyulan konular belirlenir. } \\
\text { HIE' in amaçları belirlenir. }\end{array}$ \\
\hline Tasarım & $\begin{array}{l}\text { Kazanımlar yazılır. } \\
\text { İçerik metni hazırlanır. } \\
\text { Organizasyon tasarlanır. }\end{array}$ \\
\hline Geliştirme (Yazma) & $\begin{array}{c}\text { Günlük ders planları hazırlanır. } \\
\text { Öğretim materyalleri hazırlanır. } \\
\text { Ölçme araçları hazırlanır. }\end{array}$ \\
\hline Uygulama & $\begin{array}{l}\text { Hazırlanan HİE kurs programı uygulanır. } \\
\text { Süreç değerlendirmesi yapılır. }\end{array}$ \\
\hline Değerlendirme & $\begin{array}{l}\text { Ölçme araçları uygulanır. } \\
\text { HïE kursun izleme değerlendirilmesi yapılır. } \\
\text { Hedeflere ulaşılma düzeyine karar verilir. }\end{array}$ \\
\hline
\end{tabular}

İhtiyaç Analizi aşaması: Öğretmenlerin FTT yaklaşımı ile ilgili hangi konularda hizmet-içi eğitime gereksinim duyduklarının belirlenmesi için ne, bilgi eksikliği ve yetersiz oldukları konuların saptanmasına önem verilmiştir. Bu aşamada doküman incelenme, mülakat ve gözlem teknikleri kullanılmıştır. İlk önce doküman incelemesi ile hizmet içi eğitim ve FTT yaklaşımı konusunda yapılan çalışmalar derinlemesine analiz edilmiştir. İkinci olarak öğretmenlerinin FTT ilişkisi hakkındaki düşünceleri, FTT yaklaşımı hakkındaki düşünceleri ve sınıf uygulamaları ile ilgili araştırmalar analiz edilmiştir.

Tasarım aşaması: $\mathrm{Bu}$ aşamada ihtiyaç analizinde belirlenen konular kazanım şeklinde yazılmıştır. Kazanımlar; FTT yaklaşımı anlar, Fen ve teknolojinin toplum üzerine nasıl bir etkisi olduğunu anlar, Toplumun fen ve teknoloji üzerine nasıl bir etkisi olduğunu kavrar, Fen öğretiminde FTT sorunlarının nasıl kullanılacağını öğrenir vb. şeklinde yazılmıştır. Kazanımlar doğrultusunda içerik metni yazılmıştır. HİE kurs içeriği, öğretmenlerin kurs sırasında rehber materyali olarak kullanmaları için düzenlenerek bir kılavuz kitapçık haline getirilmiştir. Kurs programını uygulanacağı yer belirlenmiş ve çalışmanın yürütüleceği sınıf kurs için hazır hale getirilmiştir. 
Geliştirme aşaması: Kurs kitapçıkları ve kurs programları öğretmenler için çoğaltılmış ve hazır hale getirilmiştir. Ayrıca kurs programının öğretmenlerin FTT ilişkisi anlamalarındaki gelişimine etkisini değerlendirmek için FTTA anketi ve öğretmenlerin HİE kurstan kazandığ 1 bilgi ve beceriyi sınıflarına yansıtma düzeylerini değerlendirmek için BORAN anketleri kurs programının pilot uygulama aşaması için çoğaltılmış ve hazır hale getirilmiştir.

Uygulama aşaması: 16 sınıf öğretmeni ile HİE programının pilot çalışması yapılmış ve uygulama süresince programın aksayan yönleri belirlenerek aksaklıklar düzeltilmiştir. Yeni oluşturulan program, Fen Bilimleri, Kimya Eğitimi, Biyoloji Eğitimi ve Eğitim Bilimleri uzmanlarına $(n=4)$ incelettirip düşünceleri alınmış ve bu düşünceler doğrultusunda HİE kurs ders planlarında, öğretmen kılavuzunda ve organizasyon yapısında gerekli olan düzeltmeler yapılmış ve HİE kursun esas uygulama aşaması için programa son hali verilmiş ve 15 sınıf öğretmenine dokuz günlük bir süreçte uygulanmıştır (Ek-1).

Değerlendirme aşaması: Kurs programı uygulandıktan sonra yapılan değerlendirme: $\mathrm{Bu}$ değerlendirme ile HİE kursun öğretmenlere kazandırmaya amaçladığı bilgi ve beceri kazanma düzeyini tespit edilmeye çalışılır. Bu süreçte birden fazla veri toplama aracı ile veri toplanılmaya dikkat edilir. Bu nedeni hedeflere ulaşma düzeyine karar vermede gerekli olan veri sayısını artırmak ve farklı kaynaklardan elde edilen verilerin birbiriyle uyumuna bakılarak varılan sonuçların geçerlilik ve güvenirliğini sağlamaktır. Bu çalışmada hazırlanan kurs programını, FTTA anketi ve ders planlarının doküman analizinden elde edilen bulgular ile değerlendirilmiştir. $\mathrm{Bu}$ aşama bünyesinde yer alan bir diğer bir değerlendirme aşamasında kursun sınıfa yansımasını değerlendiren HİE izleme değerlendirme aşamasıdır.

HİE izleme değerlendirme aşamasında yapılan değerlendirme: HİE katılan öğretmenlerin görevlerine döndükten sonra öğrendikleri bilgi ve beceriyi ne ölçüde uyguladıklarının ortaya koyulması, öğrenilenlerin iş başında uygulama veya kullanılma derecesi belirlenmesi amacıyla yapılır. Bu aşamada öğretmenlerin HİE kurstan kazandığı bilgi ve beceriyi sınıflarına yansıtma düzeylerini değerlendirmek için BORAN anketi kullanılmıştır.

\section{Veri Toplama Araçları}

Fen-Teknoloji-Toplum Anketi (FTTA): Çalışmada 15 katılımcı öğretmene uygulanan FTTA anketi, Aikenhead, Fleming ve Ryan (1989) tarafından geliştirilen çoktan seçmeli sorudan oluşan VOSTS (View on Science-Technology-Society Survey) anketinden adapte edilmiştir. Oluşturulan FTTA, 7 kategoriden ve 20 maddeden meydana gelmektedir; fen ve teknoloji doğası ( 5 madde), fen ve teknolojinin toplum üzerine etkisi (6 madde), toplumun fen ve teknoloji üzerine etkisi ( 7 madde) ve bilimsel bilginin doğası (2 madde). Ayrıca FTTA anketi maddelerin nicel analizi için alan yazına dayalı olarak bir skor şeması geliştirmiştir; doğru (3 puan), kısmen doğru 
(2 puan), yanlış (1 puan) ve ben anlamdım gibi cevaplar için (0 puan). Bu skor şeması kullanılarak katılımcıların FTTA anket maddelerinden elde ettikleri toplam puan hesaplanmıştır. Anketin güvenirlik çalışmasında iç tutarlığ s saptayabilmek için hesaplanan Cronbach alfa. 90 olarak bulunmuştur.

HİE esas uygulama aşamasında sınıf öğretmenlerinin FTTA anketi maddelerinden aldıkları toplam puanların ön-son test karşılaştırılması Wilcoxon İşaretli Sıralar Testi kullanılarak yapılmış ve analiz sonuçları tablolar halinde sunulmuştur. Ayrıca Mc Nemar testi analiz yöntemi kullanılarak katılımcı sınıf öğretmenlerinin HİE kurs öncesi FTTA anketi cevapları ile kurs sonrası cevaplarının uyumluluğunu test etmeye çalışılmıştır (Rubba, Schoneweg ve Harkness 1996). Çalışmada Rubba ve arkadaşları (1996)'nın çalışmalarına benzer olarak anketlerden elde edilen veriler 1 ve 0 koduna dönüştürülmüştür. Ankette madde ile ilgili seçeneklerden “doğru cevap'” seçilirse 1 puan ve "'kısmen doğru veya yanlış cevap seçilirse"' 0 puan verilmektedir. Çalışmada istatistiksel testte ön test ve son testten elde edilen bulgular karşılaştırmıştır.

Doküman İncelenmesinden Elde Edilen Verilerin Analizi: 15 katılımcının kurs sürecinde hazırladıkları üç ders planı analiz edilmiştir. Ders planları analiz edilirken bu materyalin belli kriterleri sağlayıp sağlamadığına bakılmış ve yeterli olup olmadığına karar verilmiştir. Ders planları konu, kazanım, öğretim yöntemi ve teknikleri ve ölçme araçları kriterler göz önüne alınarak elde edilen bulgular yazılı metin haline getirilmiştir. Daha sonra kriterlere göre araştırmacının bakış açısını da yansıtacak şekilde ayrıntılı olarak yazılı metin haline getirilmiştir. Bu yazılı metin gözden geçilerek kriterlere göre özetlenerek tablo olarak sunulmuştur.

Bütünleştirici Öğrenme Ortamı Anketi-BORAN: 6 sınıf öğretmenin sınıflarındaki öğrenme ortamını gözlemek için kullanılan BORAN anketi Keser (2003) tarafından geliştirilmiştir. BORAN anketi girme, keşfetme, açıklama, derinleştirme ve değerlendirme olarak adlandırılan 5 alt kategoriden oluşmaktadır. Gözlem anketi her bir kategoride 10 madde olmak üzere toplam 50 maddeden oluşmaktadır. Anketteki her bir ifade " gerçekleşmedi $=0$ puan, kısmen $=1$ puan, orta $=2$ puan, iyi $=3$ puan ve tamamen gerçekleşti= 4 puan', olacak şekilde değerlendirilmiştir. Anketin alt faktörlerdeki güvenirlik katsayıları 0.62 ile 0.77 arasında hesaplanmıştır. Çalışmada HİE kursun izleme değerlendirme aşamasında yer alan 6 öğretmenin sınıf uygulamaları çalışmayı yürüten araştırmacı tarafından gözlenmiş ve her bir madde için gözlem puanlarının ortalamaları alınarak çizelgede verilmiştir. Ortalamaları üç ve üzerinde olan maddenin veya basamağın istenilen düzeyde gerçekleştiği kabul edilmiştir (Keser, 2003).

Tablo 3.

HİE Kursun İzleme Aşamasında 6 Öğretmenin Gözlem Süreleri

\begin{tabular}{llllll}
\hline Öğretmen & I. Gözlem & II. Gözlem & III. Gözlem & IV. Gözlem & $\begin{array}{r}\text { Topla } \\
\text { m saat }\end{array}$ \\
\hline
\end{tabular}




\begin{tabular}{|c|c|c|c|c|c|}
\hline Ö2 & $\begin{array}{l}\text { Elektriğin günlük } \\
\text { yaşamımızdaki } \\
\text { yeri ve önemi } \\
\text { (2ders saati) }\end{array}$ & $\begin{array}{l}\text { Piller ile tanışalım } \\
\text { ( } 2 \text { ders saati) }\end{array}$ & $\begin{array}{l}\text { Elektriğin yol } \\
\text { açacağı } \\
\text { tehlikeler } \\
\text { ( } 2 \text { ders saati) }\end{array}$ & $\begin{array}{l}\text { Basit bir elektrik } \\
\text { devresi kuralım } \\
\text { (4ders saat) }\end{array}$ & 10 \\
\hline Ö5 & $\begin{array}{l}\text { Elektrikle } \\
\text { tanışalım } \\
\text { (2 ders saati) }\end{array}$ & $\begin{array}{l}\text { Farklı elektrik } \\
\text { kaynakları } \\
\text { (2ders saati) }\end{array}$ & $\begin{array}{l}\text { Piller ile } \\
\text { tanışalım } \\
\text { (2 ders saati) }\end{array}$ & $\begin{array}{l}\text { Basit bir elektrik } \\
\text { devresi kuralım } \\
\text { (4 ders saati) }\end{array}$ & 10 \\
\hline Ö8 & $\begin{array}{l}\text { Elektriğin günlük } \\
\text { yaşamımızdaki } \\
\text { yeri ve önemi (2 } \\
\text { ders saati) }\end{array}$ & $\begin{array}{l}\text { Piller ile tanışalım } \\
\text { (2 ders saati) }\end{array}$ & $\begin{array}{l}\text { Basit bir } \\
\text { elektrik devresi } \\
\text { kuralım } \\
\text { (4 ders saat,) }\end{array}$ & $\begin{array}{l}\text { Elektriği kontrol } \\
\text { edelim }(2 \text { ders } \\
\text { saati })\end{array}$ & 10 \\
\hline Ö9 & $\begin{array}{l}\text { Elektrikle } \\
\text { tanışalım } \\
\text { (2 ders saati) }\end{array}$ & $\begin{array}{l}\text { Elektriğin günlük } \\
\text { yaşamımızdaki } \\
\text { yeri ve önemi } \\
\text { (2 ders saati) }\end{array}$ & $\begin{array}{l}\text { Piller ile } \\
\text { tanışalım } \\
\text { (2 ders saati) }\end{array}$ & $\begin{array}{l}\text { Basit bir elektrik } \\
\text { devresi kuralım } \\
\text { (4ders saati) }\end{array}$ & 10 \\
\hline Ö12 & $\begin{array}{l}\text { Sesin oluşması ve } \\
\text { yayılması } \\
\text { ( } 2 \text { ders saat) }\end{array}$ & $\begin{array}{l}\text { Ses hangi } \\
\text { ortamda, nasıl } \\
\text { yayılır } \\
\text { (2 ders saati) }\end{array}$ & $\begin{array}{l}\text { Sesin } \\
\text { yayılmasını } \\
\text { önleyebilir } \\
\text { miyiz? } \\
\text { (2 ders saati) }\end{array}$ & $\begin{array}{l}\text { Sesler bize nasıl } \\
\text { yardımcı olur } \\
\text { (4 ders saati) }\end{array}$ & 10 \\
\hline Ö15 & $\begin{array}{l}\text { Sesin oluşması ve } \\
\text { yayılması } \\
\text { ( } 2 \text { ders saati) }\end{array}$ & $\begin{array}{l}\text { Ses hangi } \\
\text { ortamda, nasıl } \\
\text { yayılır } \\
\text { (2 ders saati) }\end{array}$ & $\begin{array}{l}\text { Sesin } \\
\text { yayılmasını } \\
\text { önleyebilir } \\
\text { miyiz? } \\
\text { ( } 2 \text { ders saati) }\end{array}$ & $\begin{array}{l}\text { Sesler bize nasıl } \\
\text { yardımcı olur } \\
\text { ( } 4 \text { ders saati }\end{array}$ & 10 \\
\hline
\end{tabular}

Yapılan bu gözlemlerin tutarlılığını ölçmek için ikincil araştırmacı kullanılmıştır. İkincil araştırmacının yaptığı kodlamadan sonra gözlem formları arasındaki tutarlılık yüzdeleri; Ö5 sınıfı için \%80, \%82 ve Ö9 sınıfı için \%82 ve \%84 olarak hesaplanarak ortalaması \%82 bulunmuştur. Bu sonuçlar doğrultusunda yapılan gözlemlerin güvenir olduğuna karar verilmiştir.

\section{Bulgular ve Yorum}

\section{FTTA Anketinden Elde Edilen Bulgular}

Sınıf öğretmenlerinin FTT ilişkisi hakkındaki düşüncelerindeki değişim, Tablo 4'de örneklem grubunun FTTA ön test ve son test puanlarının Wilcoxon İşaretli Sıralar Testi sonuçları verilmiştir. 
Tablo 4.

FTTA Ön Test ve Son Test Puanlarının Wilcoxon Işsaretli Sıralar Testi Sonuçları

\begin{tabular}{cccccc}
\hline Ön test-son test & $\mathrm{N}$ & $\begin{array}{c}\text { Sira } \\
\text { ortalama }\end{array}$ & Sira toplam & $\mathrm{z}$ & $\mathrm{p}$ \\
\hline Negatif sıra & - & - & - & & \\
Pozitif sıra & 15 & 8,0 & 120,0 & $-3,410^{*}$ & .001 \\
Eşit & - & - & - & & \\
\hline
\end{tabular}

*Negatif siralar temelinde

Analiz sonuçları, HİE kursa katılan sınıf öğretmenlerinin FTTA ön test ve son testinden aldıkları puanlar arasında anlamlı bir farklılık olduğu $(z=-3.410, p<.05)$ ve bu fark puanlarının sıra toplamları dikkate alındığında farkın negatif sıralar yani son test lehine olduğu görülmüştür.

Geliştirilen HİE kursun sınıf öğretmenlerinin FTT ilişkisinin hangi alt boyutlarında daha çok gelişme gösterdiğini veya hangisinde daha az gelişme göstermek için Mc Nemar Testi kullanarak karşılaştırma yapılmış ve analiz sonuçları aşağıdaki tablolarda sunulmuştur.

Tablo 5.

Öğretmenlerin FTTA Ön Test ve Son Test Puanlarının Mcnemar Testi Sonuçları

\begin{tabular}{|c|c|c|c|c|c|c|c|c|}
\hline & FTTÇA maddesi & $\mathrm{Y}$ & $\mathrm{D}$ & A & $\mathrm{p}$ & PÖ & DÖ & NÖ \\
\hline 1 & $\begin{array}{l}\text { Fen tanımlamak zordur; çünkü fen, } \\
\text { karmaşıktır ve birçok konuyla ilgilidir. }\end{array}$ & 7 & 8 & - & ,016* & $\begin{array}{l}1,3,5,6,9, \\
12,15\end{array}$ & $\begin{array}{l}2,4,7,8,1 \\
0,11,13\end{array}$ & - \\
\hline 2 & $\begin{array}{l}\text { Teknoloji Türkiye'de pek çok şey } \\
\text { yaptığı için onu tanımlamak zordur. }\end{array}$ & 7 & 8 & - &, $016^{*}$ & $\begin{array}{c}5,8-10 \\
13-15\end{array}$ & $\begin{array}{c}1-4,6,7 \\
11,12\end{array}$ & - \\
\hline 3 & $\begin{array}{l}\text { Fen ve teknoloji birbiriyle yakından } \\
\text { ilgilidir. }\end{array}$ & 8 & 6 & 1 & ,039* & $\begin{array}{l}1,3,5,8,9 \\
11,13,15\end{array}$ & $\begin{array}{c}2,4,6,7 \\
10,12\end{array}$ & 14 \\
\hline 4 & 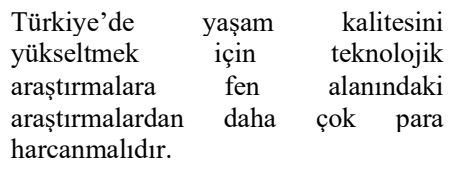 & 8 & 6 & 1 & ,039* & $\begin{array}{c}1,3,5,6 \\
9-11 \\
14\end{array}$ & $\begin{array}{l}2,4,7,8 \\
, 12,13\end{array}$ & 15 \\
\hline 5 & $\begin{array}{l}\text { Teknolojinin üzerine inşa etmek için } \\
\text { kendine ait bir bilgi yapısına sahiptir. } \\
\text { Teknolojideki çok az bir gelişme fende } \\
\text { meydana gelen keşiflerden doğrudan } \\
\text { doğruya meydana gelmektedir. }\end{array}$ & 6 & 9 & - & ,031* & $\begin{array}{l}1,3,5,10, \\
11,13\end{array}$ & $\begin{array}{c}2,4,6-9 \\
12,14 \\
15\end{array}$ & \\
\hline
\end{tabular}




\begin{tabular}{|c|c|c|c|c|c|c|c|c|}
\hline 6 & $\begin{array}{l}\text { Yeni bir teknoloji geliştirildiğinde } \\
\text { uygulamaya konabilir ya da } \\
\text { konmayabilir. Yeni bir teknolojinin } \\
\text { kullanılması kararı, temelde bu } \\
\text { teknolojinin toplum için avantajının } \\
\text { dezavantajından daha ağır basmasına } \\
\text { bağlıdır. }\end{array}$ & 8 & 7 & - & ,008* & $\begin{array}{l}1,3,5,6,8 \\
11,13,14\end{array}$ & $\begin{array}{c}2,4,7 \\
9,10,12 \\
15\end{array}$ & - \\
\hline 7 & $\begin{array}{l}\text { Teknolojik gelişmeler } \\
\text { tarafindan kontrol edilebilir. }\end{array}$ & 8 & 7 & - & $.008 *$ & $\begin{array}{l}1,3,5,6,8 \\
11,12,13\end{array}$ & $\begin{array}{l}2,4,7,9,1 \\
0,14 \\
15\end{array}$ & - \\
\hline 8 & $\begin{array}{l}\text { Hükümet politikaları ülkenin bilim } \\
\text { adamlarını etkiler. Bunun olması } \\
\text { doğaldır çünkü bilim adamları } \\
\text { toplumun bir parçasıdır(bunun anlamı, } \\
\text { bilim adamaları toplumdan } \\
\text { soyutlanamaz). }\end{array}$ & 4 & 10 & 1 &, 37 & $\begin{array}{l}1,5 \\
8,11\end{array}$ & $\begin{array}{l}2,3,4 \\
6,7,9 \\
12-15\end{array}$ & 10 \\
\hline 9 & $\begin{array}{l}\text { Türkiye Cumhuriyeti hükümeti eğitim, } \\
\text { sağlık, savunma gibi alanlar için } \\
\text { harcayacağı paradan çok daha fazlasını } \\
\text { fen ve teknoloji alanlarına harcanmas } \\
\text { gerekir. }\end{array}$ & 4 & 10 & 1 &, 37 & $\begin{array}{l}3,10,11 \\
, 13\end{array}$ & $\begin{array}{c}1,2 \\
4-9 \\
14,15\end{array}$ & 12 \\
\hline 10 & $\begin{array}{l}\text { Bazı toplumların, doğa ve insan } \\
\text { üzerine belirli görüssleri vardır. Bilim } \\
\text { adamları ve bilimsel araştırmaları, } \\
\text { çalışmanın yapıldığı yerdeki kültürün } \\
\text { dini ya da ahlaki görüşlerinden } \\
\text { etkilenirler. }\end{array}$ & 7 & 8 & - & ,016* & $\begin{array}{c}3,5 \\
6,8 \\
10,11,13\end{array}$ & $\begin{array}{c}1,2,4 \\
7,9,12 \\
14,15\end{array}$ & - \\
\hline 11 & $\begin{array}{l}\text { Türkiye'de fen ve teknolojini } \\
\text { ilerlemesi ülkenin sahip olduğu kaliteli } \\
\text { bilim adamı, mühendis ve teknisyene } \\
\text { bağlıdır. Bu yüzden Türkiye'deki } \\
\text { öğrencilerin okulda daha çok fen } \\
\text { alanında çalışması gerekir. }\end{array}$ & 6 & 7 & 2 & ,289 & $\begin{array}{c}1,3 \\
5,6 \\
11,13\end{array}$ & $\begin{array}{c}2,4 \\
7-9 \\
14,15\end{array}$ & $\begin{array}{l}10, \\
12\end{array}$ \\
\hline 12 & $\begin{array}{l}\text { Bilim adamları ve mühendisler, } \\
\text { nükleer reaktörlerin inşa edilip } \\
\text { edilemeyeceğine veya edilecekse } \\
\text { nerede inşa edilmesi gerektiğine karar } \\
\text { vermesi gereken kişilerdir, çünkü } \\
\text { gerçekleri en iyi bilenler, bilim } \\
\text { adamları ve mühendislerdir. }\end{array}$ & 6 & 9 & - & ,031* & $\begin{array}{c}1,3 \\
5,6 \\
11,13\end{array}$ & $\begin{array}{c}2,4 \\
7-10 \\
12,14 \\
15\end{array}$ & \\
\hline 13 & $\begin{array}{l}\text { Türkiye'de fen ve teknolojisi ne kadar } \\
\text { çok gelişirse, o kadar refah içinde } \\
\text { olacaktır. }\end{array}$ & 7 & 8 & - & ,016* & $\begin{array}{c}1,3,5,6,9 \\
11,13\end{array}$ & $\begin{array}{c}2,4 \\
7,8,10 \\
12 \\
14,15\end{array}$ & \\
\hline 14 & $\begin{array}{l}\text { Fen ve teknoloji insanlara bazı ahlaki } \\
\text { kararları vermesinde yardım eder. }\end{array}$ & 7 & 8 & - &, $016^{*}$ & $\begin{array}{l}6,-8 \\
11-14\end{array}$ & $\begin{array}{l}1-4,5 \\
9,10,15\end{array}$ & \\
\hline
\end{tabular}




\begin{tabular}{|c|c|c|c|c|c|c|c|c|}
\hline 15 & $\begin{array}{l}\text { Fen ve teknoloji, toplumsal } \\
\text { problemlerin( fakirlik, suç ve işsizlik } \\
\text { gibi) çözümünde önemli bir yardım } \\
\text { sağlar. }\end{array}$ & 7 & 8 & - &, $016^{*}$ & $\begin{array}{l}1,3,5,6,8 \\
11,13\end{array}$ & $\begin{array}{l}2,4,7 \\
9,10,12 \\
14,15\end{array}$ & \\
\hline 16 & $\begin{array}{l}\text { Bizler fen ve teknolojinin pozitif } \\
\text { etkileri ve negatif etkileri arasında bir } \\
\text { denge kurmak zorundayı. }\end{array}$ & 4 & 9 & 2 & ,68 & $5,7,8,14$ & $\begin{array}{l}1-, 6,9 \\
11-13 \\
15\end{array}$ & $\begin{array}{l}4, \\
10\end{array}$ \\
\hline 17 & $\begin{array}{l}\text { Bugünün problemleri olan kirlik } \\
\text { problemleri hakkında kaygılanmamız } \\
\text { gerekir. Çünkü gelecekte fen ve } \\
\text { teknoloji bu problemleri her zaman } \\
\text { çözemeye bilir. }\end{array}$ & 7 & 8 & - &, $016^{*}$ & $\begin{array}{l}1,5 \\
6,8 \\
10,12,13\end{array}$ & $\begin{array}{l}2-4 \\
9,11 \\
14,15\end{array}$ & - \\
\hline 18 & $\begin{array}{l}\text { Daha çok teknoloji Türkiye'deki } \\
\text { yaşam standardını yükseltecektir. }\end{array}$ & 5 & 9 & 1 & ,21 & $\begin{array}{l}3,5,8,12, \\
13\end{array}$ & $\begin{array}{l}1,2,4,6,7 \\
, 10,11,1 \\
4,15\end{array}$ & 9 \\
\hline 19 & $\begin{array}{l}\text { Bilim adamlarınca yapılan araştırmalar } \\
\text { doğru olarak yapılsa bile, araştırma } \\
\text { sonunda varılan bulgular zaman içinde } \\
\text { değişebilir. }\end{array}$ & 6 & 9 & - &, $031 *$ & $\begin{array}{ll}5,9, & 11, \\
12, & 13, \\
14, & \end{array}$ & $\begin{array}{l}1,2,3 \\
4,5,6,7,1 \\
0,15\end{array}$ & - \\
\hline 20 & $\begin{array}{l}\text { Araştırma laboratuvarlarında } \\
\text { kullanılan birçok model (örneğin DNA } \\
\text { modeli ve atom modeli gibi) gerçeğin } \\
\text { kopyalarıdır. }\end{array}$ & 7 & 8 & - & ,016* & $\begin{array}{l}2,3 \\
5,6 \\
11,13,14\end{array}$ & $\begin{array}{l}1,4 \\
7-10 \\
12,15\end{array}$ & - \\
\hline
\end{tabular}

$* \mathrm{p}<.05$

P: Ön testte kısmen doğru (KD) veya yanlış (Y) cevabı işaretleyip son testte doğru cevabı (D) işaretleyen ögretmen sayısı (Pozitif yöne hareket eden)

D: Ön test ve son testte de aynı kategoriye sahip cevabı işaretleyen öğretmen sayısı (Dengede kalan),

$\mathrm{N}$ : Ön testte doğru cevabı (D) işaretleyip son testte kısmen doğru (KD) veya yanlış (Y) cevabı işaretleyen öğretmen sayısı (Negatif yöne hareket eden)

PÖ: Pozitif yönde hareket eden öğretmenler

DÖ: Dengede kalan öğretmenler

NÖ: Negatif yönde hareket eden öğretmenler

Tablo 5 incelediğinde, HİE kurs sonrasında katılımcıların FTTÇA anketinin 1, 2, $3,4,5,6,7,10,12,13,14,15,17,19$ ve 20 numaralı maddeleri ile ilgili düşüncelerinde anlamlı bir değişme meydana gelirken geri kalan beş madde $(8,9,11$, 16 ve 18) ile ilgili düşüncelerinde bir anlamlı bir değişme meydana gelmediği görülmüştür.

Örnek olarak; anketin birinci maddesi ele alındığında fenin doğası ile ilgili 7 öğretmen ön teste kısmen doğru (KD) veya yanlış düşüncelere (Y) sahip iken HİE kurs sonrası son teste 8 doğru düşünceye (D) sahip olduğu ve negatif yönde hareket eden öğretmen olmadiğ́ görülmüştür.

\section{Katılımcıların hazırladıkları ders planlarından elde edilen bulgular}


Katılımcılar 5 kişilik gruplar halinde kurs süreci boyunca üç ders planı geliştirmiştir. Ders planı geliştirme sırasında öğretmenler fen bilimleri öğretim programı kitabı ve HİE kurs öğretmen rehber kitapçığından faydalanmıştır. Ders planları, konu, kazanım, yöntem ve teknik ve ölçme teknikleri kategorilerinde incelenmiştir. Ayrıca öğretmenlerin ders planlarında yer verdikleri kazanımlar FTT alt boyutu olarak, Fen-Tek., Fen-Top., Tek.-Top., Fen-Tek.-Top boyutunda analiz edilmeye çalışılmıştır (Tablo 6).

Tablo 6.

Katılımcıların Hazırladıkları Ders Planları Analizi

\begin{tabular}{|c|c|c|c|c|c|}
\hline & $\begin{array}{l}\text { Ders } \\
\text { konusu }\end{array}$ & Kazanımlar & $\begin{array}{l}\text { FTT } \\
\text { boyutu }\end{array}$ & Yöntem ve teknikleri & $\begin{array}{l}\text { Ölçme } \\
\text { yöntem ve } \\
\text { teknikleri }\end{array}$ \\
\hline \multirow[t]{2}{*}{$\begin{array}{l}1 . \\
\text { ders } \\
\text { planı }\end{array}$} & $\begin{array}{l}\text { Canlı } \\
\text { Deyince } \\
\mathrm{Ne} \\
\text { Anliyoru } \\
\text { z (A, B, C } \\
\text { grubu) }\end{array}$ & $\begin{array}{l}\text { Öğrenciler canlı varlıkları } \\
\text { özelliklerini tanımlar (A, } \\
\mathrm{B}, \mathrm{C} \text { Grubu). Öğrenciler } \\
\text { cansız varlıkların tanımlar } \\
\text { (A, B, C Grubu). } \\
\text { Çevresindeki canlı ve } \\
\text { cansız varlıklara örnekler } \\
\text { verir (A, B, C Grubu). }\end{array}$ & $\mathrm{F}$ & $\begin{array}{l}\text { Gösterim (B, C } \\
\text { Grubu), Benzetme (A } \\
\text { Grubu), } \\
\text { Soru-Cevap (A, B, C } \\
\text { Grubu), Anlatım (A, } \\
\text { B, C Grubu) }\end{array}$ & $\begin{array}{l}\text { Açıklama ve } \\
\text { kavrama } \\
\text { seviyesinde } \\
\text { açık uçlu } \\
\text { sorular (A } \\
\text { B, C Grubu) }\end{array}$ \\
\hline & $\begin{array}{l}\text { Paraşüt } \\
\text { tasarlama } \\
\text { (A } \\
\text { grubu) }\end{array}$ & $\begin{array}{l}\text { Paraşüt tasarlamanın çeşitli } \\
\text { aşamalardan oluştuğunu } \\
\text { anlar. Havada uzun süre } \\
\text { kalan paraşüt tasarlar ve } \\
\text { geliştirir. r Havanın } \\
\text { sürtünmesi faydalanılarak } \\
\text { paraşütün uçtuğunu kavrar } \\
\text { ve paraşüt tasarlamada } \\
\text { kullanır. }\end{array}$ & $\begin{array}{l}\text { F-Tek. } \\
\text { F-Tek. }\end{array}$ & $\begin{array}{l}\text { Problem çözme } \\
\text { yöntemi ve tartışma } \\
\text { teknikleri; } \\
\text { Problem durumu: } \\
\text { Paraşütle uçmayı } \\
\text { seven bir arkadaşınızın } \\
\text { havada daha çok } \\
\text { kalması için bir } \\
\text { paraşüt tasarlayalım. }\end{array}$ & \multirow{3}{*}{$\begin{array}{l}\text { Açıklama ve } \\
\text { kavrama } \\
\text { seviyesinde } \\
\text { açık uçlu } \\
\text { sorular (A, } \\
\text { B, C Grubu) }\end{array}$} \\
\hline \multirow{2}{*}{$\begin{array}{l}2 . \\
\text { ders } \\
\text { planı }\end{array}$} & $\begin{array}{l}\text { Ses } \\
\text { yalıtımı } \\
\text { (B grubu) }\end{array}$ & $\begin{array}{l}\text { Öğrenciler kendilerini } \\
\text { rahatsız eden bir aşırı ses } \\
\text { problemini çözmek için } \\
\text { düşünce, araç veya teknik } \\
\text { geliştirir. }\end{array}$ & F-Tek. & $\begin{array}{l}\text { Problem çözme } \\
\text { yöntemi ve tartışma } \\
\text { teknikleri; } \\
\text { Problem durumu: LGS } \\
\text { çalışan bir öğrenci } \\
\text { evinin karşısındaki } \\
\text { arsada yapılan inşaatın } \\
\text { aşırı gürültüsünden } \\
\text { çok fazla rahatsız } \\
\text { olmaktadır. }\end{array}$ & \\
\hline & $\begin{array}{l}\text { Küresel } \\
\text { Isınma } \\
\text { (C grubu) }\end{array}$ & $\begin{array}{l}\text { Öğrenciler yerel, ulusal ve } \\
\text { küresel çevre sorunlarını } \\
\text { bilir ve tartışır. } \\
\text { Çevre ve yaban hayatı } \\
\text { korumanın kendi ve } \\
\text { toplumun görevi olduğunu } \\
\text { anlar. }\end{array}$ & $\begin{array}{l}\text { F- Top } \\
\text { F-T-T }\end{array}$ & 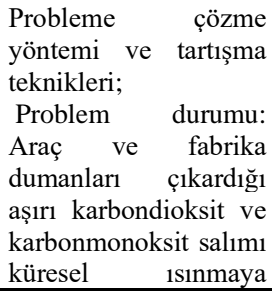 & \\
\hline
\end{tabular}




\begin{tabular}{|c|c|c|c|c|c|}
\hline \multirow{4}{*}{$\begin{array}{l}\text { Son } \\
\text { ders } \\
\text { planı }\end{array}$} & \multirow[b]{2}{*}{$\begin{array}{l}\text { Ses } \\
\text { Kirliliği } \\
\text { (A } \\
\text { grubu) }\end{array}$} & \multicolumn{2}{|l|}{$\begin{array}{l}\text { Çevresindeki doğal } \\
\text { kaynakları korumanın } \\
\text { önemini fark eder. }\end{array}$} & \multicolumn{2}{|l|}{\begin{tabular}{l}
\multicolumn{3}{l}{ sebep olmaktadır. Peki, } \\
Çayeliler olarak bu \\
kirliliği nasıl engel \\
olabiliriz.
\end{tabular}} \\
\hline & & $\begin{array}{l}\text { Ses kirliliğini çözmek için } \\
\text { araştırma yapmalı ve } \\
\text { çözüm üretmeli. } \\
\text { Ses kirliliğinin sebebinin } \\
\text { insan ve toplum olduğunu } \\
\text { bilmeli. } \\
\text { Ses kirliğinin yerel, ulusal } \\
\text { ve küresel bir çevre sorun } \\
\text { olduğunu fark etmeli. } \\
\text { Çevreyi korumanın } \\
\text { bireysel ve toplumsal } \\
\text { sorumluluk olduğunu } \\
\text { anlamalı. }\end{array}$ & $\begin{array}{l}\text { F-Tek. } \\
\text { Tek- } \\
\text { Top } \\
\text { F-T-T }\end{array}$ & 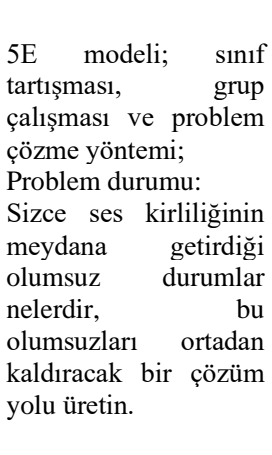 & $\begin{array}{l}\text { Performansl } \\
\text { arını } \\
\text { değerlendir } \\
\text { me rubriği; } \\
2 \text { adet Açık } \\
\text { uçlu soru } \\
\text { (analiz ve } \\
\text { sentez) }\end{array}$ \\
\hline & $\begin{array}{l}\text { Ses } \\
\text { Kirliliği } \\
\text { (B grubu) }\end{array}$ & $\begin{array}{l}\text { Ses kirliliğini çözmek için } \\
\text { araştırma yapmalı ve } \\
\text { çözüm üretmeli, ses } \\
\text { kirliliğinin sebebinin insan } \\
\text { ve toplum olduğunu } \\
\text { bilmeli. } \\
\text { Ses kirliğinin yerel, ulusal } \\
\text { ve küresel bir çevre sonu } \\
\text { olduğunu fark etmeli. } \\
\text { Çevreyi korumanın } \\
\text { bireysel ve toplumsal } \\
\text { sorumluluk olduğunu } \\
\text { anlamalı. }\end{array}$ & $\begin{array}{l}\text { F-T-T } \\
\text { F-T-T }\end{array}$ & $\begin{array}{l}\text { 5E modeli; } \\
\text { tartışması, sinıf } \\
\text { tartışması, problem } \\
\text { çözme yöntemi; } \\
\text { Problem durumu: } \\
\text { Çayeli’ndeki ses } \\
\text { kirliliğine neden olan } \\
\text { bir durumu seçiniz ve } \\
\text { bu durumu çözecek bir } \\
\text { çözüm yolu } \\
\text { geliştiriniz. }\end{array}$ & $\begin{array}{l}\text { Performansl } \\
\text { arını } \\
\text { değerlendir } \\
\text { me rubriği; } \\
\text { Açı uçlu } \\
\text { sorular; } 3 \\
\text { adet } \\
\text { (Kavrama, } \\
\text { sentez ve } \\
\text { değerlendir } \\
\text { me) }\end{array}$ \\
\hline & $\begin{array}{l}\text { Mikrosko } \\
\text { bik } \\
\text { Canlıları } \\
\text { Tanıyalı } \\
\text { m (C } \\
\text { grubu })\end{array}$ & $\begin{array}{l}\text { Öğrenciler, mikroskop } \\
\text { sayesinde mikroskobik } \\
\text { canlılar hakkında bilgi } \\
\text { sahibi olduğumuzu anlar. } \\
\text { İnsanların mercekleri } \\
\text { bulması ile mikroskobun } \\
\text { icat edildiğini fark eder. } \\
\text { Besinleri zararlı } \\
\text { mikroskobik canlılardan } \\
\text { korumada fen ve } \\
\text { teknolojin rolünü fark } \\
\text { eder. } \\
\text { Besinleri zararlı } \\
\text { mikroskobik canlılardan } \\
\text { korumak için kullanılan } \\
\text { araç ve yöntemlere örnek } \\
\text { verir ve mikroskobik } \\
\text { canlılarla ilgili meslekleri } \\
\text { bilir. }\end{array}$ & $\begin{array}{l}\text { F-Tek. } \\
\text { F-Tek. }\end{array}$ & $\begin{array}{l}\text { 5E modeli, sınıf } \\
\text { tartışması, drama, oy } \\
\text { verme, problem çözme } \\
\text { yöntemi; Problem } \\
\text { durumu: Evinizdeki } \\
\text { buzdolabının } \\
\text { bozulduğunu varsayın, } \\
\text { peki besinlerimizin } \\
\text { uzun süreli taze } \\
\text { kalmasını nasıl } \\
\text { sağlarsınız? }\end{array}$ & $\begin{array}{l}\text { Araştırma } \\
\text { ödevi; } 3 \text { açık } \\
\text { uçlu soru ( } \\
\text { Kavrama) }\end{array}$ \\
\hline
\end{tabular}

HİE kursu başlangıcında üç öğretmen grubunun hazırladıkları ilk ders planlarında FTT alt boyutlarından sadece Fen (F) bilişsel kazanımlarına yer verilmiştir. Bu 
kazanımlara yönelik öğretimi planlamak için gösterim, benzetme, soru-cevap ve anlatım yöntem ve teknikleri kullanmışlardır. Ders planlarında ölçme aracı olarak ise açıklama ve kavrama seviyesinde soruları içeren açık uçlu sorular kullanılmıştır.

HİE kursun ortasında grupların hazırladığı ikinci ders planında ise FTT alt boyutları olan F-Tek. ve F-Tek.-Top. kazanımlarına yer vermiştir. Bu kazanımlara yönelik öğretimi planlamak için problem çözme yöntemi ve tartışma teknikleri kullanmışlardır. Ders planlarında ölçme aracı olarak açıklama ve kavrama seviyesinde sorular içeren açık uçlu sorular hazırlanmıştır.

HIE kursu son ders planında ise öğretmenler tasarladığı ders planlarında FTT alt boyutları olan F-Tek. ve F-Tek.-Top. kazanımlarına yönelik kazanımlar yazmıştır. Ayrıca önceki ders planlarından farklı olarak diğer alt boyutlara oranla daha çok F-T$\mathrm{T}$ kazanımlarına yer vermişlerdir. $\mathrm{Bu}$ kazanımlara yönelik öğretimi ortamını oluşturmak için ise 5E öğrenme modeli, problem çözme yöntemi, tartışma teknikleri ve oy verme tekniklerini kullanmışlardır. Gruplar ders planlarında ölçme aracı olarak ise rubrik ve açıklama ve kavrama seviyesinde sorular içeren açık uçlu sorular kullanmışlarıdır.

\section{BORAN'dan elde edilen bulgular}

HİE kursun izleme değerlendirme aşamasında 6 öğretmenin sınıflarında dört haftalık (16 saatlik) bir uygulama yapılmıştır. Öğretmenlerin uygulamaları birer vaka olarak ele alınmış ve BORAN gözlem aracı ile ayrıntılı olarak incelenmiştir. Bu başlık altında BORAN'dan elde edilen bulgular verirlerin analizi aşağıdaki Tablo 7'de sunulmuştur.

Tablo 7.

Öğretmenlerin BORAN'nın Her Basamağına Ait Ortalama Puanları

\begin{tabular}{llllllll}
\hline Öğretmen & $\begin{array}{l}\text { 5E } \\
\text { basamakları } \\
\text { Gözlemler }\end{array}$ & Girme & Keşfetme & Açıllama & Derinleştirme & Değerlendirme & Genel \\
\hline \multirow{3}{*}{ Ö2 kodlu } & I. & 2.0 & 2.2 & 2.3 & 2.1 & 1.5 & 2.0 \\
& II. & 2.0 & 1.5 & 1.0 & 1.0 & 1.5 & 1.4 \\
& III. & 2.5 & 2.0 & 2.5 & 2.5 & 2.0 & 2.3 \\
& IV. & 2.0 & 1.0 & 3.2 & 2.1 & 1.5 & 2.0 \\
& I. & 3.3 & 3.1 & 3.5 & 2.5 & 2.5 & 3 \\
& II. & 3.3 & 3.4 & 3.5 & 2.4 & 2.5 & 3.1 \\
Ö5 kodlu & III. & 3.8 & 3.0 & 3.3 & 3.2 & 2.5 & 3.2 \\
& IV. & 3.6 & 3.5 & 3.8 & 3.5 & 3.0 & 3.5 \\
& I. & 3.6 & 3.0 & 3.7 & 3.0 & 2.0 & 3.1 \\
Ö8 kodlu & II. & 3.6 & 3.2 & 3.5 & 3.2 & 2.3 & 3.2 \\
& III. & 3.8 & 3.5 & 3.6 & 3.4 & 3.0 & 3.6 \\
\hline
\end{tabular}




\begin{tabular}{|c|c|c|c|c|c|c|c|}
\hline & IV. & 3.2 & 3.1 & 3.7 & 3.7 & 3.0 & 3.3 \\
\hline \multirow{3}{*}{ Ö9 kodlu } & I. & 3.0 & 3.7 & 3.3 & 3.2 & 3.0 & 3.2 \\
\hline & II. & 3.7 & 3.3 & 3.3 & 3.2 & 2.5 & 3.1 \\
\hline & III. & 3.7 & 3.5 & 3.6 & 3.2 & 2.5 & 3.3 \\
\hline \multirow{5}{*}{$\begin{array}{l}\text { Ö12 } \\
\text { kodlu }\end{array}$} & IV. & 3.8 & 3.5 & 3.6 & 3.8 & 3.3 & 3.6 \\
\hline & I. & 1.5 & 2.0 & 1.5 & 1.4 & 1.2 & 1.5 \\
\hline & II. & 2.5 & 3.0 & 1.2 & 2.5 & 2.5 & 2.3 \\
\hline & III. & 3.0 & 2.2 & 3.2 & 3.3 & 3.0 & 3 \\
\hline & IV. & 3.0 & 2.2 & 3.3 & 3.1 & 3.1 & 3 \\
\hline \multirow{4}{*}{$\begin{array}{l}\text { Ö15 } \\
\text { kodlu }\end{array}$} & I. & 3.0 & 1.5 & 2.5 & 1.0 & 2.0 & 2 \\
\hline & II. & 3.2 & 1.2 & 1.5 & 1.0 & 1.0 & 1.6 \\
\hline & III. & 2.0 & 1.0 & 2.0 & 2.0 & 2.0 & 1.8 \\
\hline & IV. & 1.2 & 2.0 & 2.2 & 3.0 & 2.0 & 2.1 \\
\hline
\end{tabular}

BORAN anketin de 5E basamaklarına ait ortalamalar ve genel ortalama üç ve üzerinde olması dersin istenilen düzeyde gerçekleştiği şeklinde kabul edilmiştir (Keser, 2003). Bu bağlamada tablo 8 incelediğinde Ö5, Ö8, Ö9, Ö12 kodlu öğretmenler 5E öğrenme modelini ve basamaklarını istenilen seviyede uygulamıştır. Ö2 ve Ö15 kodlu ögrretmenler ise beklenen düzeyin altında bir uygulama yapmıştır.

Bu bağlamda Ö5, Ö8, Ö9 ve Ö12 öğretmenlerin FTT yaklaşımına dayalı bir öğretim yaptığ1 ve Ö2 ve Ö15 ise geleneksel öğretmen merkezli bir ögretim yaptığ tespit edilmiştir.

\section{Tartışma, Sonuç ve Öneriler}

\section{Birinci Alt Probleme Yönelik Elde Edilen Bulguların Tartışılması}

Öğretmenlerin FTT yaklaşımı çerçevesinde fen bilgisi öğretimini benimsememelerinin temel nedenlerinden biri yeterli seviyede yaklaşıma yönelik bilgi ve beceri ile donatılmaması gösterilmektedir (Mansour, 2010). Öğretmenlerin fen bilgisi derslerinde FTT yaklaşımını kullanarak etkili bir öğretim yapmaları için fen ve teknolojinin doğası ve bunların toplum ile olan ilişkisini doğru olarak kavramalarının önemli bir etken olduğu düşünülmektedir (Amirshokoohi, 2010, 2016; Kousa, Aksela \& Savec, 2018; Mansour, 2010; Yager, 2009). Kat1lımc1 sinıf öğretmenlerine ön ve son test olarak uygulanan FTTA anketi sonuçları karşılaştırıldığında ise geliştirilen kurs sayesinde son test lehine anlamlı bir sonuç ortaya çıktığ 1 görülmüştür $(\mathrm{p}<.05)$. Diğer taraftan FTTA anketinde yer alan altı alt boyuta ilişkin bulgular analiz edildiğinde de öğretmenlerin FTT ilişkisinin alt boyutlarıyla ilgili düşüncelerinde de pozitif yönde anlamlı bir değişim meydana geldiği de görülmektedir. FTT alt boyutlarındaki değişim ele alındığında; 
HİE eğitimi sonunda 7 öğretmenin fenin doğası ile ilgili kısmen doğru veya yanlış düşüncelerinin doğru düşünceye dönüştüğü ve bu durumun tersi negatif yönde bir değişim ise yaşanmadığ 1 tespit edilmiştir $(p<.05)$. Teknolojinin doğası konusunda da benzer bir değişme görülmüş 7 öğretmenin doğru veya yanlış düşünceleri kurs sonrasında doğru düşünce yönünde değişmiştir $(\mathrm{p}<.05)$.

Öğretmenlerin fen ve teknoloji arasındaki ilişki hakkındaki düşüncelerindeki değişime bakıldığında ise, teknolojik araştırmalara fendeki araştırmalardan daha çok para harcanmalı ve teknolojideki gelişmelerin bir çok kısmı fendeki keşiflerden meydan gelmiştir maddeleri ile ilgili olarak kurs öncesi kısmen doğru veya yanlış düşüncelere sahip olan 8 öğretmenin kurs sonrasında doğru düşünceye sahip olduğu görülmüştür $(\mathrm{p}<.05)$. Bu durumda HİE kurs etkisiyle sınıf öğretmenlerinin fen ve teknolojinin doğası ve birbirleri olan ilişkisi hakkındaki yanlış ve kısmen doğru düşüncelerinin doğru düşünceye dönüştüğü söylenebilir (Ecevit, Yalaki \& Kingir, 2018).

Sınıf öğretmenlerinin toplumun fen ve teknoloji üzerine etkisi hakkındaki düşüncelerindeki değişime incelendiğinde ise geliştirilen kurs sayesinde bir çok öğretmenin bu ilişki konusunda görüşleri pozitif yönde değişmiştir; toplumun sahip olduğu değerler bilim adamlarının çalışma alanlarını etkiler (6 öğretmen; $p<.05$ ), toplum yeni bir teknolojinin uygulamaya konmasinı etkiler, toplum teknolojik gelişmeleri kontrolü eder (8 öğretmen; $\mathrm{p}<.05$ ), toplumun nükleer santral gibi teknolojik yatırımların yapılma şeklini etkiler (6 öğretmen; $\mathrm{p}<.05)$ ve hükümet politikaları bilim adamlarının araştırmalarını etkiler (4 öğretmen; p>.05) maddelerinde bir değişim ortaya çıkmıştır. Bu durumda HİE kurs sonrasında ise toplumun fen ve teknoloji üzerine etkisi ile ilgili olarak sınıf öğretmenlerinde anlamlı bir değişim olduğu söylenebilir. Wongsila ve Yuenyong (2019) ve Pimvichai, Yuenyong ve Buaraphan (2019) FTT eğitiminin bireylerin toplumsal sorunlar hakkında bilimsel bilgilerini kullanarak tartışması için bir öğretim ortamı oluşturmada başarılı olduğunu ve bireylerin bu öğrenme ortamı içerisinde yüksek sayıda nitelikli bilimsel argüman ürete bildiklerini vurgulamaktadır.

Yukardaki ilişkinin tersi olan fen ve teknolojinin toplum üzerine etkisi ile ilgili öğretmenlerin düşüncelerindeki değişim incelendiğinde ise yine bir çok öğretmenin görüşleri pozitif yönde değiştiği ortaya çıkmıştır; fen ve teknolojik gelişmeler toplumun refahını olumlu yönde etkiler ( 7 öğretmen; $p<.05$ ), fen ve teknoloji toplumsal problemlerin çözümünde önemli bir yardım sağlar ( 7 öğretmen; $p<.05$ ), fen ve teknoloji gelecekteki kirlik problemlerini de çözümler üretebilir (7 öğretmen; $\mathrm{p}<.05$ ) ve teknoloji yaşam standardını yükseltir (5 öğretmen; $\mathrm{p}>.05$ ) maddelerinde pozitif yönde değişim olmuştur. Fakat kurs öncesinde fen ve teknoloji insanların bazı ahlaki kararlarını vermesinde etkiler doğru düşünce oranında bir değişim olmamış sadece zayıf görüşe sahip olan 2 öğretmenin görüşü kısmen doğru olarak değişmiş (p>.05) ve fen ve teknolojinin pozitif etkileri ve negatif etkileri arasında bir denge kurmak zorundayız düşüncesinde de az bir değişim olmuş 4 öğretmen pozitif yönde 
görüşünü değiştirmiş̧tir ( $\mathrm{p}>$.05). Bu son iki madde anlamlı değişmenin olmamasının nedeni öğretmenlerin kurs öncesinde de bu iki durum ile ilgili anlamlı farkındalığa sahip olması gösterilebilir. Alan yazındaki çalışmalara benzer bulgular elde edilmiştir (Firmino ve arkadaşları, 2019; Yener ve arkadaşları, 2018).

FTT iliş̧kisinin en alt boyutu olan bilimsel bilginin doğası konusunda öğretmenlerin düşüncelerindeki değişime bakıldığında ise, bilimsel bilginin zaman içerisinde değişebileceğini ile ilgili kurs öncesinde yetersiz görüsse sahip olan 6 öğretmen görüşünü pozitif yönde değiştirmiştir $(\mathrm{p}<.05)$. Bilimsel modellerin de zamanla değiştiği ile ilgili ise 7 öğretmen görüşünü pozitif yönde değiştirmiştir $(\mathrm{p}<.05)$.

Geliştirilen HIE kursunun sınıf öğretmenlerinin FTT ilişkisini anlamasında etkili olduğu söylenebilir. Elde edilen sonuç araştırmacıların (Lederman; 1992, Yager, 2009, Aikenhead, 2006; Amirshokoohi, 2016) bireylerin fen ve teknolojinin sosyal yönlerinin de olduğunu anlamaları için fen ve teknoloji kaynaklı toplumsal ve çevresel sorunların yer aldığı bir fen öğrenim deneyimi yaşaması gerektiği ifadelerini doğrulamaktadır.

\section{İkinci Alt Probleme Yönelik Elde Edilen Bulguların Tartışılması}

Öğretmenlerin FTT yaklaşımına karşı olumlu bir tutuma sahip olması onların sınıflarda yaklaşımı uygulaması için önemli bir faktördür. Fakat bu durum yaklaşımı sinıflarda uygulamak için yeterli olmayabilir. Öğretmenlerin fen, teknoloji ve toplum arasındaki ilişkiyi fark etmelerinin yanında yapısalcı öğrenme kuramı ile ilgili bilgi ve becerilerinde yeterli düzeyde olması sınıflarda bu yaklaşımı istenilen düzeyde uygulanmasında önemli bir etken olduğu düşünülmektedir (Mansour, 2010). HİE kurs öncesi öğretmenlerin FTT ilişkisi ve yapısalcı öğrenme kuramı (5E modeli) hakkında yeterli bilgi ve beceriye sahip olmadığ 1 tespit edilmiştir. Kurs başlangıcında öğretmenlerin grupça geliştirdikleri ders planlarından elde edilen bulgularda bu durumu destekleyici niteliktedir. Öğretmen gruplarının geliştirdikleri ilk ders planlarında bilişsel kazanımlara yer verdikleri ve öğrencilerine bu kazanımları kazandırmak için düz anlatım, gösterim ve soru-cevap gibi öğretmen merkezli bir öğretim ortamı tasarlamak için kullanılan yöntem ve teknikleri kullandıkları görülmektedir. $\mathrm{Bu}$ duruma neden olarak öğretmenlerin hem hizmet öncesi eğitimlerinde hem de hizmet-içi eğitimlerinde yeni öğretim yaklaşımlarının sınıfta nasıl uygulanacağı konusunda yetersiz bir eğitim almaları gösterilebilir (Kousa, Aksela \& Savec, 2018; Öztürk \& Doğan, 2013). Bu durum göz önüne alınarak HİE kursta öğretmenlere FTT ilişkisi ve yapısalcı öğretim yöntem ve teknikleri ve 5E modeli hakkında bilgi ve becerileri uygulamalı olarak kazandırılmaya çalışılııştır.

HïE kurs süreci ve sonunda öğretmen grupları tarafından geliştirilen ikinci ve son ders planları incelediğinde ise FTT ilişkisinin alt boyutları olan F-Tek, F-Top, Tek.Top ve F-Tek.-Top. kazanımlarına yer verdiği ve kazanımları öğrencilere kazandırmak için öğrenme ortamını 5E modeli, proje, problem çözme, drama ve oy 
verme gibi öğretim yöntem ve teknikleri kullanarak tasarladığı tespit edilmiştir. Ayrıca ders planlarında probleme çözme yöntemi içerisinde fen ve teknoloji (F-Tek.) entegrasyonunu sağlayan ses yalıtımlı ev tasarlama, gıdaları uzun ömürlü saklama yöntemi tasarlama ve havada uzun zaman kalan paraşüt tasarlama gibi problem durumları kullanılmıştır. Özellikle son ders planları incelediğinde ise fen dersine teknoloji ve toplum entegrasyonunu (F-T-T) sağlayan ses kirliliği, küresel ısınma gibi fen ve teknoloji kaynaklı toplumsal sorunların kullanılması oldukça önemli bir gelişme olarak nitelendire bilinir. $\mathrm{Bu}$ durumda geliştirilen HİE kursun sınıf öğretmenlerinin FTT dayalı bir fen öğrenme ortamı tasarlamasında önemli bir etkisi olduğu söylenebilir. Sınıf öğretmenlerinin FTT yaklaşımı çerçevesinde fen bilgisi öğrenim ortamı tasarlama bilgisinin yeterli seviyede olmasının nedeni olarak geliştirilen kursun öğretmenlere hem fen ve teknolojinin doğası ve bunların toplum ve çevre ile olan ilişkisini doğru kavratması ve yapısalcı öğretim yöntem ve teknikleri hakkında bilgi ve beceri ile donatılması gösterilebilir (Mansour, 2010; Amirshokoohi, 2016). Diğer taraftan alan yazında da öğretmenlerin FTT yaklaşımına dayalı bir eğitim sürecini girmesinin, yaklaşımla ilgili teorik anlayışlarını oluşturmalarına, uygun öğretim yöntemlerini seçmelerine ve başarılı bir şeklide sınıfta uygulamalarına önemli bir katkı sağladığını vurgulayan çalışmalar bulunmaktadır (Mansour, 2010; Pimvichai, Yuenyong \& Buaraphan, 2019).

Ayrıca öğretmenlerin HİE kursta hazırladıkları ikinci ve son ders planları ölçme yaklaşımı bakımından incelediğinde ise 5E'nin değerlendirme basamağında konu ilgili FTT kazanımları değerlendirmek için açık uçlu soruların yer aldığı görülmüştür. $\mathrm{Bu}$ durum kursun öğretmenlere bilgi kazanımları kadar FTT kazanımların da öğrencilere kazandırılmasının önemli olduğunu anlamalarında etkili olduğunu ortaya koymaktadır. Diğer taraftan HİE kursta öğretmenler FTT kazanımlarını değerlendirmek için birçok ölçme yöntem ve teknikleri gösterilmesine rağmen ders planlarında yer alan ölçme araçlarının rubrik ve açık uçlu sorulardan oluştuğu görülmektedir. Ayrıca bu durumu HİE kursun izleme değerlendirme aşamasında 6 öğretmenin sınıf uygulamalarını değerlendiren BORAN anketi incelediğinde tüm öğretmenlerin değerlendirme bölümündeki ortalama değerin istenilen değerin hemen hemen üç puan altında olması daha net göstermektedir. Bu durum ile ilgili olarak Şenel (2008) öğretmenlerin geleneksel ölçme ve değerlendirme tekniklerini derslerinde kullanmaktan vazgeçmelerinin zor ve uzun bir süreç olduğunu bu yüzden öğretmenlere alternatif ölçme ve değerlendirme tekniklerini derslerinde kullanmalarına rehberlik edecek ve belli süreçlerde tekrar düzenlenecek somut ve uygulamalı örneklerin yer aldığı HİE kursların düzenlenmesi gerektiğini önermektedir. $\mathrm{Bu}$ bağlamda kursta yer alan ölçme ve değerlendirme derslerinin öğretmenlere bu yönde bilgi ve beceri kazandırmakta kısmen başarılı olduğu HİE kursun daha uzun süreli olması gerektiği sonucu çıkarılabilir.

Özetle; Öğretmenlerin FTT yaklaşımını sınıflarında etkili bir şekilde uygulamalarında onların FTT ilişkisini doğru bir şekilde kavramaları çok önemli bir etkendir. Bundan dolayı öğretmenlerin FTT ilişkisini tam olarak kavramaları için FTT 
sorunları üzerine tartışmaların yapıldığı ve çözüm önerilerinin geliştirildiği bir öğretim ortamı meydana getirilmelidir. Çalışmada sınıf öğretmenlerini bu ilişkiyi yaşadığı çevrede görmesi ve anlaması için üç etkinlik geliştirilse de bu konuya daha çok zaman ayırmalı, özellikle de öğretmenlerin grup olarak ele aldıkları bir FTT sorunun çözümüne yönelik projeler geliştirmeleri sağlanmalıdır. Ayrıca FTT yaklaşımına dayalı HİE kurs programına benzer çalışmaların diğer branş öğretmenleri için düzenlemesinin faydalı olabileceği düşünülmekte ve önerilmektedir

\section{Çıkar Çatışması ve Etik Bildirimi}

Yazarlar arasında çıkar çatışması bulunmadığını ve tüm araştırmacıların çalışmaya eşit oranda katkı sunduğunu beyan etmiştir. Yazarlar tüm etik kurallara uyduklarını bildirmiştir.

\section{Kaynakça}

Aikenhead, G., Fleming, R., \& Ryan, A. (1989). High-school graduates' beliefs about science-technology-society. methods and 1ssues in monitoring students views, Science Education, 71, 145-161.

Aikenhead, G.S. (2005). Research into STS science education. Educacion Quimica, 16 ,

Aikenhead, G. (2006). Science education for everyday life: Evidence-based practice (pp.21-55). Teachers College Press 384-397.

Amirshokoohi, A. (2010). Elementary pre-service teachers' environmental literacy and views toward science, technology, and society (sts) 1ssues. Science Educator, 19(1), 56-62.

Amirshokoohi, A. (2016). Impact of STS issue oriented instruction on pre-service elementary teachers' views and perceptions of science, technology and society. International Journal of Environmental and Science Education, 11(4), 359-387.

Autieri, S.M., Amirshokoohi, A., \& Kazempour, M. (2016). The science-technologysociety framework for achieving scientific literacy: an overview of the existing literatüre, European Journal of Science and Mathematics Education, 4(1), 7589.

Bennett, J., Campbell, B., Hogarth, S., \& Lubben, F. (2005). A systematic review of the effects of context-based and STS paroaches in science teaching. In C. Kasanda, L. Muhammed, S. Akpo and E. Ngololo (Eds): Proceedings of the 13th Annual Conference of the Southern African Association for Research in Mathematics, Science and Technology Education, (pp. 53-58).Windhoak, Namibia.

Chowdhury, M. A. (2016). The integration of science-technology- society/sciencetechnology-societyenvironment and socio-scientific-1ssues for effective science 
education and science teaching, Electronic Journal of Science Education, 20(5), 19-38.

Devi, M. G., \& Aznam, N. (2019).The effect of science-technology-society (STS) model on scientific literacy and scientific attitude of students on the subject of buffer, IOP Conf. Series: Journal of Physics: Conf. Series 1156 (2019) 012027 IOP Publishing https://doi.org/10.1088/1742-6596/1156/1/012027

Ecevit, T., Yalaki, Y., \& Kingir, S. (2018). Improving elementary school teacher candidates' views of nature of science through intensive education. Journal of Education in Science, Environment and Health, 4(2), 155-171. https://doi.org/10.21891/jeseh.432524

Firmino E.S., Sampaio C.G., Nojosa A.C.B., Saldanha G.C.B., Guerra M.H.F.S., Vasconcelos A.K..P. ve Barroso M.C.S. (2019). STSE Approach in High School Chemistry: A Brief Review in National Literature; Acta Scientiae, Canoas, 21(3), 196-212.

Halwany, S., Zouda, M., Pouliot, C., \& Bencze, L. (2017). Supporting pre-service teachers to teach for citizenship in the context of STSE Issues. In Bencze, L. (Ed.), Science and technology education promoting wellbeing for individuals, societies and environments: Cultural studies of science education, (pp. 405-427). New York, NY: Springer. https://doi.org/10.1007/978-3-319-55505-8_18

Keser, Ö. F. (2003). Fizik eğitimine yönelik bütünleştirici öğrenme ortamı ve tasarımı. [Yayımlanmamış doktora tezi]. Karadeniz Teknik Üniversitesi.

Kousa, P., Aksela, M., \& Savec, F. V. (2018). Pre-servıce teachers' beliefs about the benefits and challenges of STSE based school-1ndustry collaboration and practices in science education. Journal of Baltic Science Education, 17(6), 1034-1045.

Lederman, N.G. (1992). Students and teachers conceptions of the nature of science. Journal of Research in Science Teaching, 29(4), 351-359.

Mansour, N. (2010). Science teachers' perspectives on science-technology-society (STS) in science education. Eurasian Journal of Physical and Chemical Education, 2(2), 123-157.

Meyer, J.D. ve R.K. James. (2002). STS For Pre-Service Teachers: Does It Translate In The Classroom? Paper presented at the Annual Meeting of the National Association for Research in Science Teaching, Philadelphia, PA.

National Research Council [NRC] (2012). A framework for $k$-12 science education practices, crosscutting concepts, and core ideas. The National Academies Press

National Research Council [NRC] (2013). A framework for K-12 science education: Practices, crosscutting concepts, and core ideas. The National Academies Press. 
Nuutinen, H.S., Kärkkäinen, S., \& Keinonen T. (2011). Primary school pupils' perceptions of water in the context of STS study approach, International Journal of Environmental \& Science Education, 3(3), 321-339.

Öztürk Akar, E., \& Doğan, D. (2013). Turkish preservice teachers' views of sciencetechnology-society: Influence of a history of science course. Journal of Baltic Science Education, 12(6), 793-802.

Pimvichai, J., Yuenyong, C., \& Buaraphan, K. (2019). Development of grade 10 students' scientific argumentation through the science-technology-society learning unit on work and energy. Journal of Technology and Science Education, 9(3), 428-441. https://doi.org/10.3926/jotse.527

Primastuti, M., \& Atun S. (2018). Science Technology Society (STS) learning approach: an effort to improve students' learning outcomes, IOP Conf. Series: Journal of Physics: Conf. Series 1097 (2018) 012062 doi :10.1088/1742$6596 / 1097 / 1 / 012062$

Rubba, P. A., Schoneweg, B.C., \& Harkness, W.L. (1996). A new scoring procedure for the views on science, technology, society instrument, International Journal of Science Education, 18, 387-400.

Smitha, E.T., \& Aruna, P.K, (2014). Effect of science technology society approach on achievement motivation in biology of secondary school students of kasaragod district, IOSR Journal Of Humanities And Social Science, 19(4), 54-58.

Şenel, T. (2008). Fen ve Teknoloji Öğretmenleri İçin Alternatif Ölçme ve Değerlendirme Tekniklerine Yönelik Bir Hizmet-İçi Eğitim Kurs Programı Geliştirilmesi ve Etkililiğinin Araştırılması (Tez No. 213884) [Yüksek Lisans Tezi, Karadeniz Teknik Üniversitesi-Trabzon]. Yükseköğretim Kurumu Başkanlığı Ulusal Tez Merkezi.

van Eijck, M., \& Roth, W. M., (2013). Imagination of Science in Education: From epics to novelization. Springer.

Vazquez Alonso, A., Garcia Carmona, A., Manassero Mas, M. A., \& Bennassar Roig, A. (2013). Spanish secondary-school science teachers' beliefs about ScienceTechnology-Society (STS) issues. Science \& Education, 22(5), 1191-1218.

Yalaki, Y. (2014). Türkiye'de fen, teknoloji, toplum, çevre (FTTÇ) eğitimi ne durumda? Cito Eğitim: Kuram ve Uygulama, 26, 27-36.

Yalın, H. İ., Hedges, L., \& Özdemir, S. (1996). Hizmet içi eğitim program geliştirme elkitabı. Milli Eğitim Basımevi.

Yager, R. (2009). Comparing science learning among 4th-, 5th-, and 6th-grade students: STS versus textbook-based instruction, Journal of Elementary Science Education, 21(2), 15-24. 
Yener, D., Aksüt P., Kiras B., \& Yener Y. (2018). Fen bilgisi öğretmen adaylarının bilim gezisi ve fen-teknoloji-toplum-çevre konusundaki görüşleri: "Müzede bilim” örneği, Başkent University Journal of Education, 5(2), 212-224

Wongsila, S., \& Yuenyong, C. (2019). Enhancing grade 12 students' critical thinking and problem-solving ability in learning of the STS genetics and DNA technology unit. Journal for the Education of Gifted Young Scientists, 7(2), 215-235. http://dx.doi.org/10.17478/jegys.549005

\section{Extended Abstract}

In order for individuals to become science and technology literate, STS approach should be included in science education especially in primary schools and it should be educated in this direction in elementary teachers (Bennet, Hogart and Lubben; 2005). When the literature examines the literature, it is seen that this is not the case, because elementary teachers do not have sufficient knowledge about the relationship between science, technology and society, they do not have much interest in STS subjects and avoid teaching based on STS approach in classrooms (Amirshokkohi, 2010; 2016; Çınar, 2008).

In addition, research emphasizes that the use of STS approach as a teaching strategy in elementary teachers will not allow the entire subject of the lesson to be taught and students will not be successful, therefore, they also think that STS subjects are not suitable for primary school level, but rather suitable for middle and high school levels (Amirshokoohi, 2016; Autieri, Amirshokoohi \& Kazempour, 2016).

In this case, it is thought that the support of elementary teachers with trainings that include opportunities to examine their beliefs and face possible inconsistencies in their beliefs will be an important factor in implementing STS education in their classrooms. When the literature examines in this direction, most of the studies are related to the perceptions of science teachers and prospective teachers on STS education or the effect of STS-based teacher education courses on science teachers and prospective teachers (for example; Halwany, Zouda, Pouliot, \& Bencze, 2017; Kousa, Aksela \& Savec, 2018; Öztürk \& Doğan, 2013; Vazquez Alonso, Garcia Carmona, Manassero Mas \& Bennassar Roig, 2013).

Little research has been done on the perceptions of elementary teachers and candidates on STS education or the impact of STS-based teacher education courses on their beliefs (Amirshokkohi, 2016). In this context, it was seen as a problem situation that the elementary teachers' studies were very low in order to ensure their professional development in STS approach, and a nine-day in-house course was developed, implemented and its effectiveness was investigated.

The developed course study was carried out at the Recep Tayyip Erdogan University Education Faculty with the classroom teachers working in Rize. In the 
investigation of the effectiveness of course, special case research method was adopted. This research method contributed significantly to the focus on the course developed for the researcher and to understand the effectiveness of the course on 15 elementary teachers, understanding the interrelationship of cause-effect and variables. The FTTA questionnaire was used to determine the effect of the course developed in the study in understanding the STS relationship, the BORAN observation scale was used to determine the teachers' ability to teach science based on the STS approach and Document analysis of the lesson plans to determine the course acquisition level.

The study group was formed by selecting among the elementary teachers working in Rize province. Before the working group was formed, all elementary teachers in the province were informed about the study and those who wanted were contacted on a voluntary basis. The research was carried out with 31 volunteer elementary teachers. During the pilot implementation phase of the course, 16 of these teachers worked. Deficiencies arising during the pilot implementation were arranged and the actual implementation of the course was made ready for the study.

During the main application phase, 15 elementary teachers (9 Men, 6 Women) were studied. In addition, after the actual application phase, the monitoring and evaluation phase of the HIE course was carried out with 6 class teachers selected voluntarily among 15 teachers to investigate the situation of elementary teachers to reflect their knowledge and skills to science teaching in their classes.

It can be said that the developed course is effective in understanding the STS relationship of classroom teachers. The result obtained confirms the researchers' (Lederman, 1992; Yager, 2009, Aikenhead, 2006; Amirshokoohi, 2016) expresses that individuals should have a science learning experience with social and environmental problems related to science and technology in order to understand that they also have social aspects of science and technology. In addition, it can be said that the developed course has an important effect on elementary teachers' designing a STSbased science learning environment. The course developed as the reason for the fact that the teachers have sufficient knowledge of designing a science learning environment within the framework of the STS approach can be shown to teachers to correctly understand the nature of science and technology and their relationship with society and the environment, and to be equipped with knowledge and skills about constructive teaching methods and techniques (Mansour, 2010, Amirshokoohi 2016).

\section{Ek-1}

Tablo 8.

HïE Kurs Programı

\begin{tabular}{llll}
\hline Haf & Konu & Saat & İçrik \\
\hline
\end{tabular}




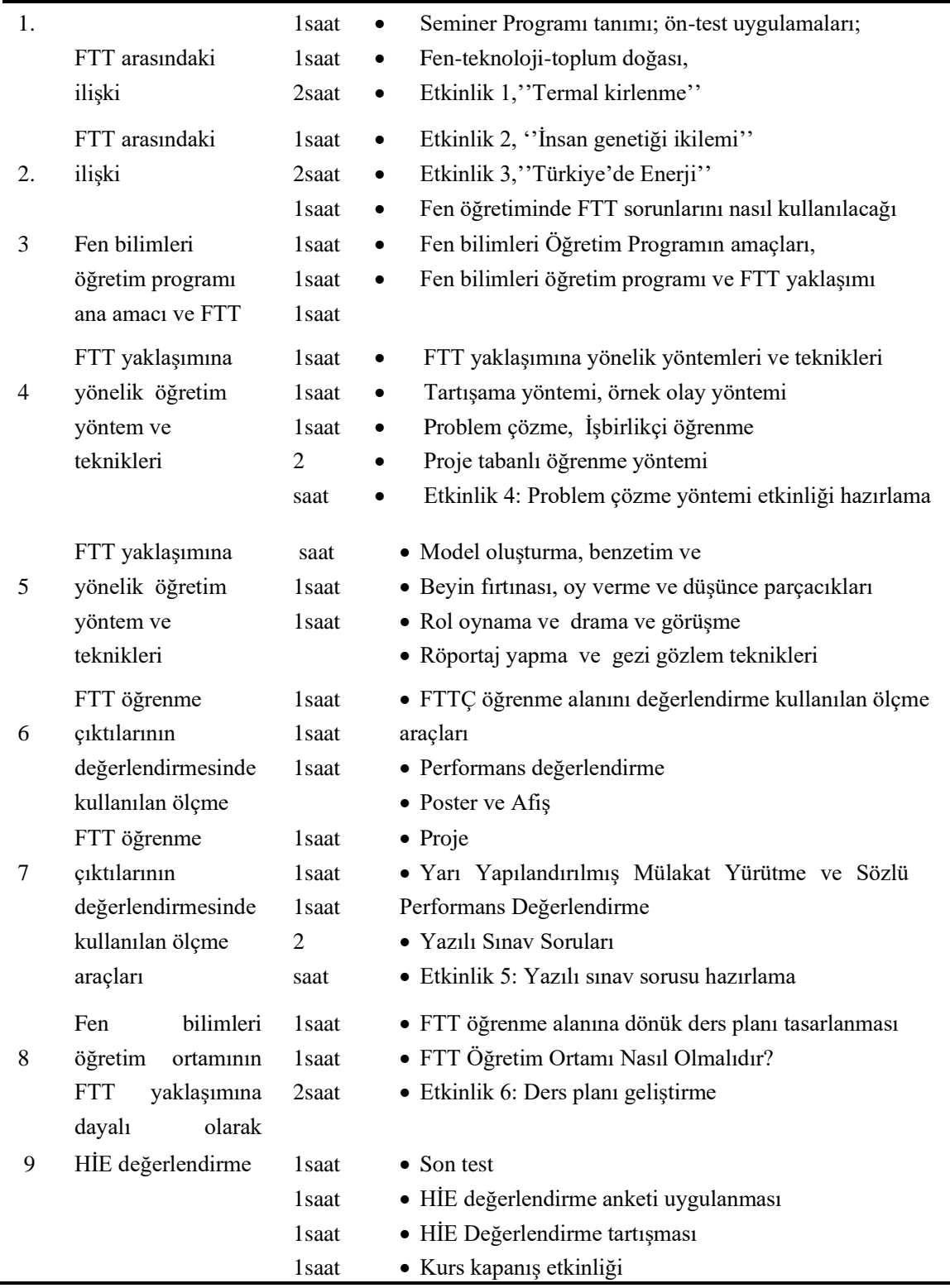

